\title{
Sprawozdanie z działalności Studencko- -Doktoranckiego Logopedycznego Koła Naukowego na Wydziale Filologicznym UŁ w latach 2014-2018
}

Studencko-Doktoranckie Logopedyczne Koło Naukowe działające na Wydziale Filologicznym Uniwersytetu Łódzkiego przy Zakładzie Dialektologii Polskiej i Logopedii powstało 19 maja 2014 roku, a formalną działalność rozpoczęło 1 października 2014 roku. Opiekunem koła została prof. nadzw. UŁ dr hab. Renata Marciniak-Firadza, która do dziś pełni tę funkcję. Członkami koła są studenci studiów licencjackich na kierunku logopedia $\mathrm{z}$ audiologią oraz studiów magisterskich na kierunku logopedia, a także doktoranci Wydziału Filologicznego UŁ.

Celem koła jest rozwijanie u członków zainteresowań związanych głównie z diagnozą i terapią logopedyczną różnych zaburzeń mowy oraz popularyzacja wiedzy logopedycznej wśród nauczycieli przedszkoli i szkół oraz uczniów łódzkich szkół gimnazjalnych i ponadgimnazjalnych.

Członkowie koła angażują się w różne formy aktywności, między innymi organizację i prowadzenie dla zainteresowanych osób i grup zorganizowanych warsztatów z emisji głosu, wykładów otwartych poświęconych wadom wymowy i ich eliminowaniu, współpracę z innymi kołami naukowymi działającymi na Uniwersytecie Łódzkim. Ponadto regularnie organizowane są różnego rodzaju warsztaty, szkolenia i zajęcia dodatkowe.

W roku 2014 w ciągu trzech miesięcy działalności odbyły się trzy spotkania członków koła: spotkanie organizacyjne, w trakcie którego omówione zostały plany

\footnotetext{
* Zakład Dialektologii Polskiej i Logopedii, Instytut Filologii Polskiej i Logopedii, Wydział Filologiczny Uniwersytetu Łódzkiego, ul. Pomorska 171/173, 90-236 Łódź, e-mail: mateusz.szurek@uni.lodz.pl.
} 
naukowe koła (październik), spotkanie naukowe poświęcone mowie rozszczepowej, na którym wykład wygłosiła prof. Danuta Pluta-Wojciechowska, oraz spotkanie międzyuczelniane (UŁ, UM, PŁ) kół naukowych, będące okazją do prezentacji koła logopedycznego oraz nawiązania współpracy z innymi kołami (listopad). Ponadto członkowie koła zorganizowali i poprowadzili warsztaty z emisji głosu dla uczniów Publicznego Gimnazjum nr 19 w Łodzi (grudzień).

Studencko-Doktoranckie Logopedyczne Koło Naukowe w 2015 roku zorganizowało sześć spotkań naukowych. Pierwsze z nich poświęcone było omówieniu testów diagnostycznych wykorzystywanych przez logopedów (marzec). Na kwietniowym zebraniu prof. nadzw. UŁ dr hab. Renata Marciniak-Firadza przeprowadziła warsztaty poświęcone metodzie osiemnastu struktur sylabowych. Na spotkaniu w październiku członkowie omówili plan działań na rok akademicki 2015/2016. W ramach kolejnych trzech spotkań zorganizowano: wideokonferencję z Kamilą Czachorowską - logopedą pracującą w Anglii - której celem było pokazanie, jak wygląda praca z polskimi dziećmi za granicą (listopad); badania audiometryczne słuchu dla studentów i pracowników Uniwersytetu Łódzkiego (grudzień); warsztaty z języka migowego (grudzień).

W 2016 roku członkowie koła zorganizowali cztery spotkania naukowe na terenie uczelni oraz dziewięć poza uczelnią. W styczniu uczestniczyli w Nocy z Filologią, podczas której zaprezentowali kierunki logopedia $\mathrm{z}$ audiologią oraz logopedia, a także przybliżyli zainteresowanym osobom działalność koła. Podczas spotkania lutowego wzięli udział w warsztatach pt. Terapia ręki, przeprowadzonych przez dwie członkinie koła. Warsztaty poświęcone mutyzmowi wybiórczemu, prowadzone przez prof. nadzw. UŁ dr hab. Renatę Marciniak-Firadzę, były tematem spotkania marcowego. W czerwcu zorganizowano pierwszą debatę logopedyczną wśród studentów kierunków logopedia $\mathrm{z}$ audiologią oraz logopedia dotyczącą problemu ankyloglosji. Na spotkaniu w pierwszej połowie października omówiono plany naukowe koła na rok akademicki 2016/2017. W grudniu odbyły się warsztaty pt. Specyfika pracy logopedy w zakładzie opiekuńczo-leczniczym, przeprowadzone przez mgr Karinę Wichurską. W ramach działalności koła studenci i doktoranci uczestniczyli również $\mathrm{w}$ warsztatach pt. Elementy integracji sensorycznej w terapii logopedycznej, przeprowadzonych przez dr Magdalenę Olempską-Wysocką w Specjalistycznej Poradni Psychologiczno-Pedagogicznej Doradztwa Zawodowego i dla Dzieci z Wadami Rozwojowymi w Łodzi (kwiecień). Ponadto członkowie koła zorganizowali i przeprowadzili: warsztaty dla dzieci w wieku przedszkolnym w ramach III Kongresu Edukacyjnego Łódzkiego Towarzystwa Pedagogicznego (styczeń); zajęcia metodą ruchu rozwijającego Weroniki Sherborne w Przedszkolu Miejskim nr 36 Integracyjnym w Łodzi (styczeń); warsztaty z emisji głosu dla uczniów Zespołu Szkół Ponadgimnazjalnych nr 9 przygotowujących spektakl do XX Przeglądu Twórczości Artystycznej Szkół Zawodowych (kwiecień). W roku 2016 koło nawiązało także współpracę z: Przedszkolem Miejskim nr 36 Integracyjnym w Łodzi (cotygodniowy wolontariat członków koła); Przedszkolem Miejskim nr 109 z Oddziałami Integracyjnymi w Łodzi 
(w którym przeprowadzono cykl zajęć logorytmicznych); Łódzkim Towarzystwem Alzheimerowskim (cykl zajęć logopedycznych październik-grudzień), a także z Kołem Sympatyków Dydaktyki Polonistycznej działającym przy Zakładzie Dydaktyki Języka i Literatury Polskiej UŁ.

W roku 2017 zorganizowano łącznie sześć spotkań naukowych. W lutym odbył się wykład na temat skali Brazeltona przygotowany przez członkinię koła. Studencko-Doktoranckie Logopedyczne Koło Naukowe promowało się również podczas Dnia Otwartego Wydziału Filologicznego Uniwersytetu Łódzkiego, na którym zaprezentowało ofertę dydaktyczną Zakładu Dialektologii Polskiej i Logopedii (marzec) oraz przeprowadziło dwa warsztaty dla uczniów szkół ponadgimnazjalnych: warsztat audiologiczny Chodza słuchy... Nie bądź głuchy! oraz warsztat z emisji głosu i techniki mówienia Poczuj w sobie siłę lwa!. W marcu odbyło się spotkanie z Bartoszem Wojtkowskim zatytułowane Zespół Tourette’a - szczerze, wesoło, $z$ dystansem, na którym prowadzący opowiedział o specyfice choroby. Pod koniec roku akademickiego odbyły się aż cztery warsztaty: Robotyka $w$ logopedii i terapii pedagogicznej - przeprowadzony przez mgr Annę Grzegory, Mind the Mind (warsztat psychologiczny) - przygotowany przez studentki psychologii Uniwersytetu Łódzkiego, Jak pracować $z$ dzieckiem $z$ ORM? - autorstwa dr Ewy Gackiej oraz Lego $w$ logopedii - z udziałem mgra Jacka Suligi. Ponadto członkowie koła uczestniczyli w Ogólnopolskiej Konferencji Jak skutecznie wspierać rozwój mowy u dzieci - wyzwania stojące przed wspótczesna logopeda zorganizowanej przez Centrum Kształcenia Dobra Kadra w Warszawie (marzec), a także przygotowali i przeprowadzili zajęcia logorytmiczne zatytułowane Wiosenne zabawy logorytmiczne dla podopiecznych Domu Dziecka dla Małych Dzieci w Łodzi w ramach wydarzenia Dzień Dziecka z Wydziałem Filologicznym UŁ (czerwiec). Wraz z początkiem nowego roku akademickiego członkowie koła rozpoczęli cykliczne warsztaty logorytmiczne w łódzkich przedszkolach (Przedszkole Miejskie nr 36 Integracyjne, Przedszkole Miejskie nr 109 z Oddziałami Integracyjnymi) oraz warsztaty z emisji głosu dla uczniów XV Liceum Ogólnokształcącego w Łodzi. W listopadzie w ramach akcji organizowanej przez Urząd Miasta Łodzi przy współpracy Uniwersytetu Łódzkiego najbardziej uzdolnieni licealiści z województwa łódzkiego wzięli udział w warsztatach z emisji głosu przeprowadzonych przez członków koła.

W 2018 roku Studencko-Doktoranckie Logopedyczne Koło Naukowe także aktywnie uczestniczyło w życiu akademickim. W styczniu odbyły się warsztaty przygotowane przez Ewę Sobczak - terapeutkę zajęciową zmagającą się od dzieciństwa z czterokończynową spastyczną postacią mózgowego porażenia dziecięcego. W marcu, jak co roku, członkowie koła wzięli udział w Dniu Otwartym Wydziału Filologicznego, podczas którego tradycyjnie przedstawili ofertę dydaktyczną Zakładu Dialektologii Polskiej i Logopedii. Studentki przygotowały dla uczniów szkół ponadgimnazjalnych warsztaty z języka migowego oraz warsztaty audiologiczne, podczas których uczniowie mieli możliwość zapoznać się ze sposobami badania słuchu i przy 
okazji wykorzystać zdobytą wiedzę w praktyce. Dodatkowo najaktywniejsze studentki koła uczestniczyły w VII Ogólnopolskiej Konferencji Naukowo-Szkoleniowej Terapia logopedyczna. Strategie - metody - techniki zorganizowanej przez Naukowe Koło Logopedów i Audiologów Uniwersytetu Marii Curie-Skłodowskiej. Rok akademicki został zakończony zebraniem organizacyjnym, na którym podsumowano wszystkie minione wydarzenia.

Studencko-Doktoranckie Logopedyczne Koło Naukowe UŁ jest jednym z najaktywniej działających kół na Wydziale Filologicznym i cieszy się niesłabnącym zainteresowaniem ze strony studentów. Motywuje to jego członków do podejmowania nowych, ciekawych aktywności, które prowadzą do rozwijania umiejętności praktycznych już podczas studiów. 